\title{
Underreporting of energy intake among Japanese women aged 18-20 years and its association with reported nutrient and food group intakes
}

\author{
Hitomi Okubo and Satoshi Sasaki* \\ National Institute of Health and Nutrition, 1-23-1 Toyama, Shinjuku-ku, Tokyo 162-8636, Japan
}

Submitted 24 November 2003: Accepted 4 May 2004

\begin{abstract}
Objectives: To evaluate the ratio of energy intake to basal metabolic rate (EI/BMR) among young female Japanese adults, and to compare the lifestyle and dietary characteristics between relatively low and high reporters.

Design: Dietary intakes were assessed over a 1-month period with a validated, selfadministered, diet history questionnaire, and lifestyle variables were assessed by a second questionnaire designed for this survey. The ratio of EI/BMR was calculated from reported energy intake and estimated basal metabolic rate.

Subjects: In total, 1889 female Japanese university students aged 18-20 years who were enrolled in dietetics courses.

Results: Ninety-five per cent of the subjects were classified into a non-obese group (body mass index (BMI) $<25 \mathrm{~kg} \mathrm{~m}^{-2}$; mean \pm standard deviation (SD): $20.8 \pm 2.6 \mathrm{~kg} \mathrm{~m}^{-2}$ ). EI/BMR was $1.43 \pm 0.40$ (mean $\pm \mathrm{SD}$ ). Sixty-eight per cent of the subjects showed an EI/BMR level below the possibly balanced value of $1.56,37 \%$ showed EI/BMR below the minimum survival value of 1.27 and $2 \%$ of the subjects showed EI/BMR exceeding the maximum value for a sustainable lifestyle of 2.4. BMI, body weight and BMR decreased significantly with the increase in EI/BMR $(P<0.001)$. The percentage of energy from carbohydrate was significantly higher, whereas those from fat and protein were significantly lower, among the lower EI/BMR groups. As for food groups, a significantly declining trend from the lowest to the highest EI/BMR groups was observed for cereals.

Conclusion: Underreporting, rather than overreporting, of energy intake was predominant in this relatively lean Japanese female population. BMI was the most important factor affecting the reporting accuracy of energy intake.
\end{abstract}

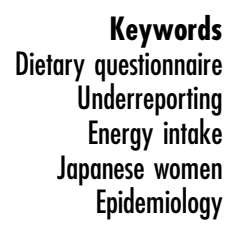

An accurate assessment of habitual dietary intake is very important in determining the association between diet and disease. Several dietary assessment methods have been developed, validated and used in dietary surveys. However, any method used to assess self-reported dietary intake is not entirely able to avoid reporting errors ${ }^{1}$. Most dietary surveys may include not only random errors but also systematic errors, such as the misreporting of true intake by certain subject groups ${ }^{2,3}$.

In the 1980s, the development of the doubly labelled water technique, which measured the total energy expenditure of subjects in free-living situations ${ }^{4,5}$, made it possible to validate reported energy intake as an external biomarker $^{6-8}$. However, the high cost of the technique has restricted its use to relatively small-scale studies. As an alternative approach to detect misreporting of energy intake, Goldberg et al. $^{9}$ introduced the ratio of reported energy intake to basal metabolic rate (EI/BMR). Many investigators who have used the Goldberg cut-off value to identify underreporters ${ }^{10}$ have indicated that reporting errors have been associated with subject characteristics ${ }^{3}$. However, almost all studies on this issue were conducted in Western countries such as in Europe ${ }^{11-14}$, the USA ${ }^{15}$ and Australia $^{16}$. No studies have been performed in Asian countries except one dealing with pregnant Indonesian women ${ }^{17}$.

The purpose of the present study was to evaluate EI/BMR values in order to examine the prevalence of misreporting of energy intake in female Japanese students and the relationship between reported energy intake and body mass index (BMI) and nutrient intakes.

\section{Subjects and methods}

\section{Subjects}

The subjects were freshmen who were enrolled in dietetics courses at 22 colleges and technical schools in Japan in April $1997(n=2069)$. All the questionnaires were 
distributed between 7 and 21 April 1997. A total of 2063 students (2017 women and 46 men) returned the answered questionnaires within 1 week (response rate of 99.7\%). Faculty members of each school checked the submitted questionnaires. When missing replies and/or errors were found, the subjects were requested to answer the questions again. All questionnaires were checked at least once by local staff and once by staff of the study centre. The entire survey was completed before the end of May.

\section{Assessment of dietary habits}

We used a self-administered diet history questionnaire (DHQ). The DHQ is a validated, 16-page questionnaire assessing dietary habits in the previous month. Intakes of 147 food items, 16 nutrients and total energy intake were calculated using an ad hoc computer algorithm developed to analyse the questionnaire. More detailed descriptions of the questionnaire, methods of calculating nutrients and the validity are given elsewhere ${ }^{18,19}$. The 147 foods from the DHQ were grouped into 17 food groups, mainly according to the food composition tables of Japanese foods, 4 th revised edition ${ }^{20}$. In this study, sugar, nuts, and mushrooms and sea vegetables were categorised into confectioneries, pulses and vegetables, respectively, because the mean intakes of these items were much lower than those of other food groups.

\section{Assessment of lifestyle variables}

Lifestyle variables were obtained from the 4-page questionnaire designed for this survey. It included the frequency of sports club activity and smoking habits. The physical activity level was assessed by the monthly frequency of sports club activity only, without inquiring into the types of sport, their intensity or duration. The subjects who engaged in sports club activity at least once per week in the previous month were defined as 'physically active' and the others as 'sedentary'. Smoking habits were divided into three categories: never, former and current smokers. Data on birth date, and self-reported body weight and height - to the nearest $\mathrm{kg}$ and $\mathrm{cm}$, respectively, were obtained from the DHQ. BMI was calculated as body weight $(\mathrm{kg})$ divided by the square of body height $\left(\mathrm{m}^{2}\right)$. We classified BMI into three categories according to the Japan Society for the Study of Obesity ${ }^{21}$ : $<18.5 \mathrm{~kg} \mathrm{~m}^{-2}, 18.5-25 \mathrm{~kg} \mathrm{~m}^{-2}$ and $\geq 25 \mathrm{~kg} \mathrm{~m}^{-2}$ as 'lean', 'normal' and 'obese', respectively.

\section{Estimation of BMR}

BMR was estimated for each subject using the formula for women aged 18-30 years based on body weight, given by the Food and Agriculture Organization/World Health Organization/United Nations University (FAO/
WHO/UNU) ${ }^{22}$ as follows:

$$
\begin{aligned}
& \text { Estimated BMR }\left(\mathrm{MJ} \mathrm{day}^{-1}\right) \\
& \quad=0.0615 \times \text { body weight }(\mathrm{kg})+2.08 \text {. }
\end{aligned}
$$

\section{Statistical analysis}

For the purpose of statistical analysis we selected only women who completed the questionnaires $(n=2017)$, and we included 1889 subjects (93.7\%) who satisfied the following three criteria in the analysis:

1. Those aged $18-20$ years on the surveyed day $(n=1960)$;

2. Those with information on sports club activity and smoking habits ( $n=1988)$; and

3. Those with reported energy intake of more than or equal to half of the energy requirement of the lowest physical activity category and less than 1.5 times the energy requirement of the highest physical activity category $^{23}$, i.e. the subjects with reported energy intake of $3.0-14.4 \mathrm{MJ} \mathrm{day}^{-1}(n=1980)$.

We calculated the EI/BMR ratio to evaluate the validity of energy intake. To compare the relative degree of underand overreporting, we temporarily used the values defined by $\mathrm{FAO} / \mathrm{WHO} / \mathrm{UNU}^{22}$ : the minimum survival level of 1.27 , the sedentary level for women of 1.56 , and the maximum sustainable lifestyle level of 2.0-2.4. We classified the subjects into quintiles of EI/BMR. Distribution of anthropometric and dietary variables across quintiles of EI/BMR was evaluated by calculating the means of these variables for each quintile.

Nutrient intakes were energy-adjusted using the energy density model, i.e. the percentage of energy intake for macronutrients and $\mathrm{g} / \mathrm{mg} / \mu \mathrm{g}$ per $10 \mathrm{MJ}$ energy intake for micronutrients and food groups. The results are given only with the adjustment for sports club activity, because other variables such as smoking and alcohol drinking habits were not statistically different across quintiles of EI/BMR.

We tested the differences across quintiles of EI/BMR by using the PROC GLM procedure with the LSMEANS statement. The chi-square test was used to test for proportionate differences between categories. All statistical analyses were performed using version 8.2 of the SAS software package (SAS Institute, Inc., Cary, NC, USA). A $P$-value of $<0.05$ was considered significant.

\section{Results}

The characteristics of the subjects are shown in Table 1 . BMI for all subjects was $20.8 \pm 2.6 \mathrm{~kg} \mathrm{~m}^{-2}$ (mean \pm standard deviation (SD)). Ninety-five per cent of the subjects were classified into a non-obese group (BMI $<25 \mathrm{~kg} \mathrm{~m}^{-2}$ ). Energy intake was $7.5 \pm 2.0 \mathrm{MJ} \mathrm{day}^{-1}$ (mean $\pm \mathrm{SD}$ ). The frequency of sports club activity was $1.7 \pm 4.1$ days per month (mean $\pm \mathrm{SD}$ ). Eighty-eight per cent of the subjects participated in sports club activity 
Table 1 Characteristics of the subjects $(n=1889)$. Values are expressed as mean \pm standard deviation, unless specified otherwise

\begin{tabular}{lc}
\hline Age (years) & $18.1 \pm 0.4$ \\
Body weight $(\mathrm{kg})$ & $51.8 \pm 7.3$ \\
Body height $(\mathrm{cm})$ & $157.9 \pm 5.2$ \\
Reported El $\left(\mathrm{MJ}_{\text {day }}{ }^{-1}\right)$ & $7.5 \pm 2.0$ \\
BMR $\left(\mathrm{MJ} \mathrm{day}^{-1}\right)^{\star}$ & $5.3 \pm 0.5$ \\
El/BMR & $1.43 \pm 0.40$ \\
BMI $\left(\mathrm{kg} \mathrm{m}^{-2}\right)$ & $20.8 \pm 2.6$ \\
$<18.5(\%)$ & 16 \\
$18.5-25.0(\%)$ & 79 \\
$\geq 25.0(\%)$ & 5 \\
Sports club activity (days/month) & $1.7 \pm 4.1$ \\
$\quad$ Sedentary (\%) & 88 \\
Active (\%)† & 12 \\
Smoking habits (\%) & \\
Current & 3 \\
Former & 3 \\
$\quad$ Never & 94 \\
Alcohol drinking habits (\%) & \\
Non-drinker & 80 \\
Drinker & 20
\end{tabular}

$\mathrm{EI}$ - energy intake; BMR - basal metabolic rate; BMI - body mass index. * BMR was calculated by the Food and Agriculture Organization/World Health Organization/United Nations University formula (1985) ${ }^{22}$

† Subjects who participated in sports club activity at least once per week were defined as 'active'.

less than once per week during the previous month. Regarding smoking habits, most of the subjects (97\%) were current non-smokers. Eighty per cent were nondrinkers. EI/BMR for all subjects was $1.43 \pm 0.40$ (mean \pm SD). Figure 1 shows the distribution of EI/BMR values. The distribution is slightly skewed to the right. Some $68 \%$ and $37 \%$ of subjects showed lower EI/BMR when we compared EI/BMR with the possibly balanced value of 1.56 and the minimum survival level of $1.27^{22}$, respectively. On the other hand, $2 \%$ of the subjects showed EI/ BMR exceeding the maximum value for a sustainable lifestyle of 2.4 .

Table 2 shows mean values of body weight and height, BMI, BMR and EI by quintile of EI/BMR. A significant declining trend from the lowest to the highest quintile of
EI/BMR was observed for body weight, BMI and BMR. As for sports club activity, the proportion of the physically active group increased slightly with increasing EI/BMR. The percentage of current smokers and alcohol drinkers was not statistically different between quintiles of EI/BMR.

Table 3 presents mean energy and nutrient intakes by quintile of EI/BMR. Mean fat intake expressed as a percentage of total energy increased with increasing EI/ BMR. A similar tendency was seen for saturated fatty acids, monounsaturated fatty acids and polyunsaturated fatty acids. On the other hand, the energy intake derived from carbohydrate decreased with increasing EI/BMR. Vitamin $\mathrm{C}$ did not correlate significantly with EI/BMR.

Table 4 presents the mean intakes of food groups by quintile of EI/BMR. When intake was expressed per $10 \mathrm{MJ}$ of energy intake, a significant declining trend from the lowest to the highest quintile of EI/BMR was seen for cereals. A significantly positive correlation was observed for confectioneries, fats and oil, fish, and meats. As for pulses and non-sugar containing soft drinks, neither correlated significantly with EI/BMR.

\section{Discussion}

This is the first study to report an inverse relationship between BMI and EI/BMR among young Japanese women. Some previous papers reported that obese subjects in Western countries tended to underreport their energy intake $e^{2,3,24}$. Despite the fact that the subjects of the present study were relatively lean, $37 \%$ of them showed an EI/BMR level below the minimum survival value of 1.27 , whereas $2 \%$ of the subjects showed EI/BMR exceeding the maximum value for a sustainable lifestyle of 2.4. In the six previous studies dealing with adult populations with cutoff values for EI/BMR from $<1.20$ to $<1.28$, the mean ratio of underreporters was $40 \%{ }^{3}$, which was similar to the rate of possible underreporters in this female Japanese population. This indicates that they tended to underreport,

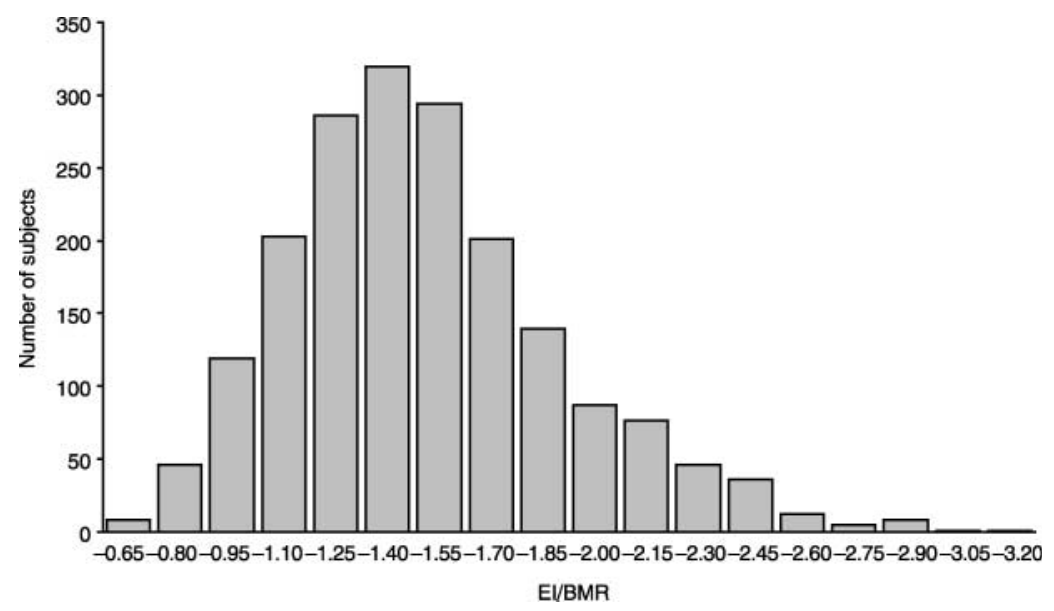

Fig. 1 Distribution of the ratio of energy intake to basal metabolic rate (EI/BMR). Values on horizontal axis show the upper limit of each range $(n=1889)$ 
Table 2 Values of anthropometric characteristics and lifestyle variables by quintile of El/BMR. Values are expressed as mean \pm standard deviation, unless specified otherwise

\begin{tabular}{|c|c|c|c|c|c|c|}
\hline & \multicolumn{5}{|c|}{ Quintile of El/BMR } & \multirow[b]{2}{*}{$P$-value } \\
\hline & $\begin{array}{l}\text { First quintile } \\
(n=377)\end{array}$ & $\begin{array}{l}\text { Second quintile } \\
\quad(n=378)\end{array}$ & $\begin{array}{l}\text { Third quintile } \\
(n=378)\end{array}$ & $\begin{array}{l}\text { Fourth quintile } \\
\quad(n=378)\end{array}$ & $\begin{array}{l}\text { Fifth quintile } \\
(n=378)\end{array}$ & \\
\hline El/BMR & $0.94 \pm 0.12$ & $1.20 \pm 0.06$ & $1.38 \pm 0.05$ & $1.59 \pm 0.08$ & $2.05 \pm 0.26$ & $<0.001$ \\
\hline Body weight (kg) & $54.8 \pm 9.2$ & $52.5 \pm 7.1^{\star \star \star}$ & $51.7 \pm 6.7^{\star \star \star}$ & $50.6 \pm 5.8^{\star \star \star}$ & $49.5 \pm 5.9^{\star \star \star}$ & $<0.001$ \\
\hline Body height $(\mathrm{cm})$ & $158.2 \pm 5.3$ & $158.0 \pm 5.2$ & $157.9 \pm 5.2$ & $157.9 \pm 5.2$ & $157.8 \pm 5.1$ & 0.896 \\
\hline BMI $\left(\mathrm{kg} \mathrm{m}^{-2}\right)$ & $21.9 \pm 3.3$ & $21.0 \pm 2.6^{\star \star \star}$ & $20.8 \pm 2.4^{\star \star \star}$ & $20.3 \pm 2.1^{\star \star \star}$ & $19.9 \pm 2.0^{\star \star \star}$ & $<0.001$ \\
\hline BMR (MJ day $\left.{ }^{-1}\right)$ & $5.5 \pm 0.6$ & $5.3 \pm 0.4^{\star \star *}$ & $5.3 \pm 0.4^{\star \star *}$ & $5.2 \pm 0.4^{\star \star \star}$ & $5.1 \pm 0.4^{* \star *}$ & $<0.001$ \\
\hline Energy intake (MJ day $\left.{ }^{-1}\right)$ & $5.1 \pm 0.8$ & $6.4 \pm 0.6^{\star \star \star}$ & $7.3 \pm 0.6^{\star \star \star}$ & $8.3 \pm 0.7^{\star \star \star}$ & $10.5 \pm 1.7^{\star \star \star}$ & $<0.001$ \\
\hline Sports club activity (days/month) & $1.46 \pm 3.79$ & $1.52 \pm 3.58$ & $1.54 \pm 4.29$ & $1.87 \pm 4.18$ & $1.92 \pm 4.33$ & 0.365 \\
\hline Sedentary $(\%) \dagger$ & 90 & 89 & 90 & 85 & 85 & 0.052 \\
\hline Active (\%) $\ddagger$ & 10 & 11 & 10 & 15 & 15 & \\
\hline \multicolumn{7}{|l|}{ Smoking habits (\%)† } \\
\hline Current & 4 & 3 & 3 & 2 & 3 & 0.221 \\
\hline Former & 4 & 3 & 2 & 3 & 3 & \\
\hline Never & 92 & 94 & 95 & 96 & 94 & \\
\hline \multicolumn{7}{|l|}{ Alcohol drinking habits $(\%) \dagger$} \\
\hline Non-drinker & 79 & 82 & 79 & 83 & 76 & 0.130 \\
\hline Drinker & 21 & 18 & 21 & 17 & 24 & \\
\hline
\end{tabular}

EI - energy intake; BMR - basal metabolic rate; BMI - body mass index.

† Percentage of the subjects (\%): significant differences between all categories by chi-square test.

$\ddagger$ Subjects who participated in sports club activity at least once per week were defined as 'active'.

Significance level compared with the first quintile of El/BMR: ${ }^{\star \star \star}, P<0.001$.

rather than to overreport, their energy intake, similar to the situation observed in Western populations.

To evaluate the validity of energy intake and to identify underreporters, the Goldberg cut-off value has been used widely $^{14,24-27}$. We did not use the value in the present study, however, for the following two reasons. First, we did not collect enough information to estimate the physical activity level of the population, which is needed to use the Goldberg cut-off value ${ }^{28}$. Second, the purpose of the present study was to evaluate EI/BMR, and to investigate its association with reported nutrient and food group intakes rather than to detect under- or overreporters. In this analysis, we excluded 36 subjects with energy intakes of less than $3.0 \mathrm{MJ} \mathrm{day}^{-1}$ or more than $14.4 \mathrm{MJ} \mathrm{day}^{-1}$. We also conducted the analyses including these 36 subjects $(n=1925)$. The results did not change materially (data not shown).

We used the standard formula proposed by FAO/ $\mathrm{WHO} / \mathrm{UNU}^{22}$. But the prediction formulas for BMR might be inadequate for estimating the true BMR in Japanese populations. According to a previous report, the BMR calculated from the FAO/WHO/UNU formula (1985) was $103 \mathrm{kcal} \mathrm{day}^{-1}\left(314 \mathrm{~kJ} \mathrm{day}^{-1}\right)$ higher than the measured BMR in female Japanese populations aged 6.8-78.5 years $^{29}$. Taking this into account, our results might overestimate the number of underreporters. To the contrary, the range of $2.0-2.4$, which is suggested as the maximum value for a sustainable lifestyle, was included in the fifth quintile of EI/BMR. Therefore, the results should be interpreted cautiously both for possible under- and

Table 3 Intakes of energy and nutrients by quintile of El/BMR. Values are expressed as mean \pm standard deviation†

\begin{tabular}{|c|c|c|c|c|c|c|}
\hline & \multicolumn{5}{|c|}{ Quintile of El/BMR } & \multirow[b]{2}{*}{$P$-value } \\
\hline & $\begin{array}{l}\text { First quintile } \\
(n=377)\end{array}$ & $\begin{array}{l}\text { Second quintile } \\
\quad(n=378)\end{array}$ & $\begin{array}{l}\text { Third quintile } \\
\qquad(n=378)\end{array}$ & $\begin{array}{l}\text { Fourth quintile } \\
\qquad(n=378)\end{array}$ & $\begin{array}{l}\text { Fifth quintile } \\
(n=378)\end{array}$ & \\
\hline Total fat (\% of energy) & $26.5 \pm 6.0$ & $29.2 \pm 6.0^{\star \star \star}$ & $30.0 \pm 6.0^{\star \star \star}$ & $32.4 \pm 5.9^{\star \star \star}$ & $34.0 \pm 5.9^{\star \star \star}$ & $<0.001$ \\
\hline SFA (\% of energy) & $8.2 \pm 2.2$ & $9.2 \pm 2.2^{\star \star *}$ & $9.5 \pm 2.2^{\star * \star}$ & $10.1 \pm 2.1^{\star \star *}$ & $10.5 \pm 2.1^{\star \star *}$ & $<0.001$ \\
\hline MUFA (\% of energy) & $9.2 \pm 2.5$ & $10.3 \pm 2.5^{\star \star \star}$ & $10.6 \pm 2.5^{\star \star \star}$ & $11.5 \pm 2.4^{\star \star \star}$ & $12.2 \pm 2.4^{\star \star \star}$ & $<0.001$ \\
\hline PUFA ( $\%$ of energy) & $6.4 \pm 2.0$ & $7.0 \pm 2.0^{\star \star *}$ & $7.1 \pm 2.0^{\star \star *}$ & $7.8 \pm 2.0^{\star \star *}$ & $8.1 \pm 2.0^{\star \star \star}$ & $<0.001$ \\
\hline Protein ( $\%$ of energy) & $14.0 \pm 2.7$ & $14.5 \pm 2.6^{\star \star}$ & $14.7 \pm 2.7^{\star \star \star}$ & $15.0 \pm 2.6^{\star \star \star}$ & $14.7 \pm 2.6^{\star \star \star}$ & $<0.001$ \\
\hline Carbohydrate ( $\%$ of energy) & $58.0 \pm 7.1$ & $55.0 \pm 7.1^{\star \star \star}$ & $54.0 \pm 7.1^{\star \star \star}$ & $51.6 \pm 6.9^{\star \star \star}$ & $50.0 \pm 6.9^{\star \star \star}$ & $<0.001$ \\
\hline Alcohol (\% of energy) & $0.3 \pm 1.1$ & $0.2 \pm 1.1^{\star}$ & $0.2 \pm 1.1$ & $0.2 \pm 1.1^{\star}$ & $0.4 \pm 1.1$ & 0.013 \\
\hline Calcium (mg/10 MJ) & $699 \pm 293$ & $755 \pm 292^{* *}$ & $769 \pm 293^{\star \star \star}$ & $806 \pm 285^{\star \star \star}$ & $776 \pm 285^{\star \star *}$ & $<0.001$ \\
\hline Iron (mg/10 MJ) & $10.7 \pm 2.8$ & $11.2 \pm 2.8^{\star \star}$ & $11.3 \pm 2.8^{\star \star \star}$ & $11.7 \pm 2.7^{\star \star \star}$ & $11.4 \pm 2.7^{\star \star \star}$ & $<0.001$ \\
\hline Sodium (mg/10 MJ) & $4440 \pm 1517$ & $4740 \pm 1511^{\star \star}$ & $4708 \pm 1518^{\star \star}$ & $4901 \pm 1476^{\star \star \star}$ & $4974 \pm 1478^{\star \star \star}$ & $<0.001$ \\
\hline Vitamin C (mg/10 MJ) & $154.5 \pm 80.1$ & $148.7 \pm 79.8$ & $153.4 \pm 80.1$ & $159.5 \pm 77.9$ & $152.0 \pm 78.0$ & 0.153 \\
\hline Dietary fibre $(\mathrm{g} / 10 \mathrm{MJ})$ & $16.6 \pm 5.3$ & $16.5 \pm 5.3$ & $16.5 \pm 5.3$ & $16.8 \pm 5.2$ & $15.9 \pm 5.2^{\star \star}$ & 0.001 \\
\hline
\end{tabular}

EI - energy intake; BMR - basal metabolic rate; SFA - saturated fatty acids; MUFA - monounsaturated fatty acids; PUFA - polyunsaturated fatty acids. $\dagger$ Mean values were adjusted by sports club activity.

Significance level compared with the first quintile of El/BMR: *, $P<0.05 ;{ }^{* *}, P<0.01$; ${ }^{* * *}, P<0.001$. 
Table 4 Intakes of food groups ( $\mathrm{g} / 10 \mathrm{MJ}$ ) by quintile of El/BMR. Values are expressed as mean \pm standard deviation

\begin{tabular}{|c|c|c|c|c|c|c|}
\hline & \multicolumn{5}{|c|}{ Quintile of El/BMR } & \multirow[b]{2}{*}{$P$-value } \\
\hline & $\begin{array}{l}\text { First quintile } \\
\quad(n=377)\end{array}$ & $\begin{array}{l}\text { Second quintile } \\
\quad(n=378)\end{array}$ & $\begin{array}{l}\text { Third quintile } \\
\qquad(n=378)\end{array}$ & $\begin{array}{l}\text { Fourth quintile } \\
\quad(n=378)\end{array}$ & $\begin{array}{l}\text { Fifth quintile } \\
(n=378)\end{array}$ & \\
\hline Cereals & $663.0 \pm 158.5$ & $574.2 \pm 157.8^{\star \star \star}$ & $546.3 \pm 158.6^{\star \star \star}$ & $474.8 \pm 154.1^{\star \star \star}$ & $427.4 \pm 154.3^{\star \star \star}$ & $<0.001$ \\
\hline Potatoes & $45.6 \pm 31.2$ & $42.9 \pm 31.0^{\star \star \star}$ & $44.9 \pm 31.2^{* \star *}$ & $46.1 \pm 30.3^{\star \star \star}$ & $48.5 \pm 30.4^{* \star *}$ & 0.025 \\
\hline Confectioneries $†$ & $84.0 \pm 55.9$ & $94.2 \pm 55.7$ & $96.7 \pm 55.9^{\star}$ & $98.7 \pm 54.3^{\star \star \star}$ & $110.0 \pm 54.4^{\star \star \star}$ & $<0.001$ \\
\hline Fats and oil & $22.3 \pm 18.9$ & $24.5 \pm 18.9$ & $25.0 \pm 18.9$ & $30.1 \pm 18.4^{\star \star \star}$ & $33.7 \pm 18.4^{\star \star \star}$ & $<0.001$ \\
\hline Pulses & $62.9 \pm 49.1$ & $68.1 \pm 48.9$ & $65.9 \pm 49.1$ & $71.0 \pm 47.7^{\star}$ & $63.5 \pm 47.8$ & 0.089 \\
\hline Fruits & $128.7 \pm 150.8$ & $128.4 \pm 150.2$ & $130.2 \pm 150.9$ & $154.3 \pm 146.6^{\star \star}$ & $150.0 \pm 146.9^{\star}$ & 0.011 \\
\hline Total vegetables§ & $293.5 \pm 170.3$ & $292.7 \pm 169.6$ & $300.2 \pm 170.4$ & $311.1 \pm 165.6$ & $292.0 \pm 165.9$ & 0.047 \\
\hline \multicolumn{7}{|l|}{ Soft drinks } \\
\hline Sugar-containing & $44.9 \pm 100.5$ & $43.3 \pm 100.5$ & $50.7 \pm 100.5$ & $48.1 \pm 100.5$ & $65.5 \pm 100.6^{\star \star}$ & 0.017 \\
\hline Non-sugar containing & $20.8 \pm 66.7$ & $15.6 \pm 66.7$ & $20.7 \pm 66.7$ & $13.3 \pm 66.7$ & $19.7 \pm 66.7$ & 0.317 \\
\hline Fish & $80.7 \pm 53.6$ & $88.3 \pm 53.4^{*}$ & $91.6 \pm 53.6^{\star \star}$ & $95.3 \pm 52.1^{\star \star \star}$ & $98.5 \pm 52.2^{\star \star \star}$ & $<0.001$ \\
\hline Meats & $77.0 \pm 45.7$ & $83.3 \pm 45.5^{*}$ & $87.1 \pm 45.7^{\star \star \star}$ & $92.5 \pm 44.4^{\star \star \star}$ & $97.7 \pm 44.5^{\star \star \star}$ & $<0.001$ \\
\hline Eggs & $38.9 \pm 34.1$ & $41.4 \pm 34.0$ & $42.1 \pm 34.2$ & $43.0 \pm 33.2$ & $36.1 \pm 33.2$ & 0.011 \\
\hline Dairy products & $188.8 \pm 182.5$ & $211.9 \pm 181.7^{*}$ & $217.5 \pm 182.6^{*}$ & $232.5 \pm 177.4^{\star * *}$ & $213.0 \pm 177.7^{\star}$ & 0.003 \\
\hline
\end{tabular}

EI - energy intake; BMR - basal metabolic rate.

Energy-adjusted values by density method were used for analysis.

† Including sugar and sweetners.

$\ddagger$ Including animal fat and vegetable fat.

$\S$ Including green and yellow vegetables, non-green and yellow vegetables, mushrooms and sea vegetables.

Significance level compared with the first quintile of El/BMR: ${ }^{*}, P<0.05 ;{ }^{\star *}, P<0.01 ;{ }^{* \star}, P<0.001$.

overreporters. In addition, we applied BMR and BMI calculated from self-reported body weight and height. They might be biased (for example, see reference 30). However, some studies have reported that BMI calculated from self-reported body height and weight correlated highly with measured $\mathrm{BMI}^{31,32}$. These studies suggest that BMI calculated from self-reported body weight and height is, at least, a reliable measure for use in association analyses. We have therefore used these values both in our previous paper ${ }^{33}$ and the present report.

Several previous studies have examined non-dietary factors such as physiological and psychological factors associated with energy intake $\mathrm{e}^{3,26,34,35}$. Here, we examined the effects of physical activity, smoking habits and alcohol intake on reported energy intake (Table 2). The proportion of the active group was increasing slightly, whereas that of the sedentary group was decreasing, along with the increase in EI/BMR, which indicates that a more active lifestyle is associated with higher energy requirements. As for psychological factors, we examined the association between EI/BMR and desire for body weight change, expressed as the difference between ideal and present BMI (data not shown). We observed a linear trend between EI/BMR and the difference in BMI. However, when present BMI, the difference between ideal and present BMI, sports club activity and smoking habits were entered in a model for multiple regression analysis, the difference between ideal and present BMI did not reach a significant level. Therefore, present BMI seems, at least in this population, to be the most important factor affecting the reporting of food intakes and predicting underreporting.

We examined whether low-energy reporters underreported all nutrients equally or reported some specific nutrients lower than others. Energy from carbohydrate was significantly higher, whereas that from fat was significantly lower, in the lower quintiles of EI/BMR (Table 3). Among the micronutrients examined, vitamin $\mathrm{C}$ was not significantly different across the EI/BMR groups. According to the review by Livingstone and Black ${ }^{3}$, energy from protein tends to be reported significantly higher, whereas that from fat is reported lower, in low-energy reporters.

Few studies have examined the bias in reporting of meal patterns and the types of food consumed ${ }^{26,36,37}$. In previous studies, low-energy reporters tended to report the consumption of 'socially desirable' foods such as fish, fruit and salad higher, whereas 'socially undesirable' foods such as snacks, cakes, sugar and fats were reported lower. According to Hebert et al. ${ }^{38}$, women show higher 'social desirability' scores associated with lower reported fat and energy intakes than do men. In the present study (Table 4), the reported intake of cereals was higher, while in contrast intakes of confectioneries, fats and oil, fish and meats were lower, in the lower EI/BMR groups. We analysed the data on soft drinks divided into sugar-containing and nonsugar containing drinks. Neither type of drink correlated significantly with EI/BMR, which is somewhat different from the results observed in Western populations ${ }^{27}$.

Our results might not be representative because the subjects were not a random sample of the general Japanese population, but selected female dietetics students aged 18-20 years. Because they were freshmen enrolled in dietetics courses, the participants in this study might be highly health-conscious. To minimise the influence of nutritional education, we finished the survey within almost one month after their entrance to the course. According to the Japanese National Nutrition Survey in 1998, the percentages of subjects aged 15-19 years with 
BMI $<18.5 \mathrm{~kg} \mathrm{~m}^{-2}$ and $\geq 25 \mathrm{~kg} \mathrm{~m}^{-2}$ were $20 \%$ and $6 \%$, respectively 39 . It was $16 \%$ and $5 \%$, respectively, in the present study. The distribution of BMI was not markedly different between the two surveys. Compared with Western populations ${ }^{40}$, Japanese women are generally leaner in this age range. Nevertheless, we observed the tendency of underreporting, rather than overreporting, similar to that found in Western populations. This indicates that inaccuracy of energy intake should be taken into account when the results of dietary surveys are interpreted, even in a non-obese population such as young Japanese women.

In summary, our study found a significant correlation between BMI and EI/BMR. Moreover, a majority of the subjects underreported their energy intake in spite of being relatively lean. However, the participants in this study were not representative of the Japanese population as a whole. Further studies are needed to examine whether the correlations observed in the present study are commonly observed in other Asian as well as in other Japanese populations.

\section{Acknowledgements}

We wish to thank Drs Keiko Amano, Akane Katagiri, Taeko Shimoda, Tomiko Tsuji and Hatsuko Yamamoto for study planning and data collection, and Shoko Matsunaga for data processing.

\section{References}

1 Barrett-Connor E. Nutrition epidemiology: how do we know what they ate? American Journal of Clinical Nutrition 1991; 54(Suppl. 1): 182S-7S.

2 Black AE, Cole TJ. Biased over- or under-reporting is characteristic of individuals whether over time or by different assessment methods. Journal of the American Dietetic Association 2001; 101: 70-80.

3 Livingstone MB, Black AE. Markers of the validity of reported energy intake. Journal of Nutrition 2003; 133(Suppl. 3): 895S-920S.

4 Schoeller DA. Recent advances from application of doubly labeled water to measurement of human energy expenditure. Journal of Nutrition 1999; 129: 1765-8.

5 Schoeller DA. Validation of habitual energy intake. Public Health Nutrition 2002; 5(6A): 883-8.

6 Black AE, Coward WA, Cole TJ, Prentice AM. Human energy expenditure in affluent societies: an analysis of 574 doublylabelled water measurements. European Journal of Clinical Nutrition 1996; 50: 72-92.

7 Hill RJ, Davies PS. The validity of self-reported energy intake as determined using the doubly labelled water technique. British Journal of Nutrition 2001; 85: 415-30.

8 Trabulsi J, Schoeller DA. Evaluation of dietary assessment instruments against doubly labeled water, a biomarker of habitual energy intake. American Journal of Physiology. Endocrinology and Metabolism 2001; 281(5): E891-9.

9 Goldberg GR, Black AE, Jebb SA, Cole TJ, Murgatroyd PR, Coward WA, et al. Critical evaluation of energy intake data using fundamental principles of energy physiology. 1. Derivation of cut-off values to identify under-recording. European Journal of Clinical Nutrition 1991; 45: 569-81.
10 Black AE, Goldberg GR, Jebb SA, Livingstone MBE, Cole TJ, Prentice AM. Critical evaluation of energy intake data using fundamental principals of energy physiology: 2. Evaluating the results of published surveys. European Journal of Clinical Nutrition 1991; 45: 583-99.

11 Fogelholm M, Männisto S, Vartiainen E, Pietinen P. Determinants of energy balance and overweight in Finland 1982 and 1992. International Journal of Obesity and Related Metabolic Disorders 1996; 20: 1097-104.

12 Price GM, Paul AA, Cole TJ, Wadsworth MEJ. Characteristics of the low-energy reporters in a longitudinal national dietary survey. British Journal of Nutrition 1997; 77: 833-51.

13 Voss S, Kroke A, Klipstein-Grobusch K, Boeing H. Is macronutrient composition of dietary intake data affected by underreporting? Results from the EPIC-Potsdam study. European Journal of Clinical Nutrition 1998; 52: 119-26.

14 McGowan MJ, Harrington KE, Kiely M, Robson PJ, Livingstone MBE, Gibney MJ. An evaluation of energy intakes and the ratio of energy intake to estimated basal metabolic rate $\left(\mathrm{EI} / \mathrm{BMR}_{\mathrm{est}}\right)$ in the North/South Ireland Food Consumption Survey. Public Health Nutrition 2001; 4(5A): 1043-50.

15 Briefel RR, Sempos CT, McDowell MA, Chien S, Alaimo K. Dietary methods research in the third National Health and Nutrition Examination Survey: under-reporting of energy intake. American Journal of Clinical Nutrition 1997; 65: S1203-9.

16 Heywood P, Harvey PJW, Marks GC. An evaluation of energy intake in the 1983 Australian National Dietary Survey of Adults. European Journal of Clinical Nutrition 1993; 47: 604-6.

17 Winkvist A, Persson V, Hartini TNS. Underreporting of energy intake is less common among pregnant women in Indonesia. Public Health Nutrition 2002; 5(4): 523-9.

18 Sasaki S, Yanagibori R, Amano K. Self-administered diet history questionnaire developed for health education: a relative validation of the test-version by comparison with 3-day diet record in women. Journal of Epidemiology 1998; 8: $203-15$.

19 Sasaki S, Ushio F, Amano K, Morihara M, Todoriki O, Uehara $\mathrm{Y}$, et al. Serum biomarker-based validation of a selfadministered diet history questionnaire for Japanese subjects. Journal of Nutritional Science and Vitaminology 2000; 46(6): 285-96.

20 Science and Technology Agency. Standard Tables of Food Composition in Japan, 4th revised ed. Tokyo: Printing Bureau, Ministry of Finance, 1982 [in Japanese].

21 Matsuzawa Y, Inoue S, Ikeda Y, Sakata T, Saito Y, Sato Y, et al. The judgment criteria for new overweight, and the diagnostic standard for obesity. Obesity Research 2000; 6: 18-28 [in Japanese].

22 Food and Agriculture Organization/World Health Organization/United Nations University (FAO/WHO/UNU). Energy and Protein Requirements. Report of a Joint FAO/ WHO/UNU Expert Consultation. Technical Report Series No. 724. Geneva: WHO, 1985.

23 Ministry of Health and Welfare. Recommended Dietary Allowance for Japanese: Dietary Reference Intakes, 6th revised ed. Tokyo: Ministry of Health and Welfare, 1999 [in Japanese].

24 Braam LA, Ocke MC, Bueno-de-Mesquita HB, Seidell JC. Determinants of obesity-related underreporting of energy intake. American Journal of Epidemiology 1998; 147(11): 1081-6.

25 Ferrari P, Slimani N, Ciampi A, Trichopoulou A, Naska A, Lauria C, et al. Evaluation of under- and overreporting of energy intake in the 24-hour diet recalls in the European Prospective Investigation into Cancer and Nutrition (EPIC). Public Health Nutrition 2002; 5(6B): 1329-45.

26 Matthys C, De Henauw S, Devos C, De Backer G. Estimated 
energy intake, macronutrient intake and meal pattern of Flemish adolescents. European Journal of Clinical Nutrition 2003; 57(2): 366-75.

27 Johansson L, Solvoll K, Bjørneboe G-EA, Drevon CA. Underand overreporting of energy intake related to weight status and lifestyle in a nationwide sample. American Journal of Clinical Nutrition 1998; 68: 266-74.

28 Black AE. Critical evaluation of energy intake using the Goldberg cut-off for energy intake:basal metabolic rate. A practical guide to its calculation, use and limitations. International Journal of Obesity and Related Metabolic Disorders 2000; 24: 1119-30.

29 Yamamura C, Kashiwazaki H. Factors affecting the postabsorptive resting metabolic rate of Japanese subjects: reanalysis based on published data. Japanese Journal of Nutrition 2002; 60(2): 75-83 [in Japanese].

30 Rovira RF, Pons IF, Martinez MI, Sanchez RR. Self-reported versus measured height, weight and body mass index in Spanish Mediterranean teenagers: effects of gender, age and weight on perceptual measures of body image. Annals of Nutrition \& Metabolism 2002; 46: 68-72.

31 Goodman E, Hinden BR, Khandelwal S. Accuracy of teen and parental reports of obesity and body mass index. Pediatrics 2000; 106: 52-8.

32 Kuczmarski MF, Kuczmarski RJ, Najjar M. Effects of age on validity of self-reported height, weight, and body mass index: findings from the Third National Health and Nutrition Examination Survey, 1988-1994. Journal of the American Dietetic Association 2001; 101: 28-34.

33 Sasaki S, Katagiri A, Tsuji T, Shimoda T, Amano K. Self-reported rate of eating correlates with body mass index in 18-y-old Japanese women. International Journal of Obesity and Related Metabolic Disorders 2003; 27: 1405-10.

34 Asbeck I, Mast M, Bierwag A, Westenhöfer J, Acheson KJ, Müller MJ. Severe underreporting of energy intake in normal weight subjects: use of an appropriate standard and relation to restrained eating. Public Health Nutrition 2002; 5(5): 683-90.

35 Kant AK. Interaction of body mass index and attempt to lose weight in a national sample of US adults: association with reported food and nutrient intake, and biomarkers. European Journal of Clinical Nutrition 2003; 57(2): 249-59.

36 Burns C, Jackson M, Gibbons C, Stoney RM. Foods prepared outside the home: association with selected nutrients and body mass index in adult Australians. Public Health Nutrition 2002; 5(3): 441-8.

37 Berteus Forslund H, Lindroos AK, Sjostrom L, Lissner L. Meal patterns and obesity in Swedish women - a simple instrument describing usual meal types, frequency and temporal distribution. European Journal of Clinical Nutrition 2002; 56(8): 740-7.

38 Hebert JR, Clemow L, Pbert L, Ockene IS, Ockene JK. Social desirability bias in dietary self-report may compromise the validity of dietary intake measures. International Journal of Epidemiology 1995; 24: 389-98.

39 Ministry of Health and Welfare. Kokumin Eiyou no Genjou [Annual Report of the National Nutrition Survey in 1998]. Tokyo: Ministry of Health and Welfare, 2000; 45-6 [in Japanese].

40 Schoenborn CA, Adams PF, Barnes PM. Body weight status of adults: United States, 1997-98. Advance Data 2002; 6(330): $1-15$. 